\title{
Article
}

\section{Eating Habits during the COVID-19 Pandemic and the Level of Antibodies IgG and FRAP-Experiences of Polish School Staff: A Pilot Study}

\author{
Anna Puścion-Jakubik ${ }^{1, *,+(\mathbb{D}, \text { Ewa Olechno }}{ }^{2,+}$, Katarzyna Socha ${ }^{1} \mathbb{D}$ and Małgorzata Elżbieta Zujko ${ }^{2}(\mathbb{D}$ \\ 1 Department of Bromatology, Faculty of Pharmacy with the Division of Laboratory Medicine, \\ Medical University of Białystok, Mickiewicza 2D Street, 15-222 Białystok, Poland; \\ katarzyna.socha@umb.edu.pl \\ 2 Department of Food Biotechnology, Faculty of Health Science, Medical University of Białystok, \\ Szpitalna 37 Street, 15-295 Białystok, Poland; ewa.olechno@sd.umb.edu.pl (E.O.); \\ malgorzata.zujko@umb.edu.pl (M.E.Z.) \\ * Correspondence: anna.puscion-jakubik@umb.edu.pl; Tel.: +48-8574-854-69 \\ + These authors contributed equally to this work.
}

Citation: Puścion-Jakubik, A.; Olechno, E.; Socha, K.; Zujko, M.E. Eating Habits during the COVID-19 Pandemic and the Level of Antibodies IgG and FRAP-Experiences of Polish School Staff: A Pilot Study. Foods 2022, 11, 408. https://doi.org/10.3390/ foods11030408

Academic Editor: Elizabeth H. Zandstra

Received: 30 December 2021 Accepted: 27 January 2022 Published: 30 January 2022

Publisher's Note: MDPI stays neutral with regard to jurisdictional claims in published maps and institutional affiliations.

Copyright: (c) 2022 by the authors. Licensee MDPI, Basel, Switzerland. This article is an open access article distributed under the terms and conditions of the Creative Commons Attribution (CC BY) license (https:// creativecommons.org/licenses/by/ $4.0 /)$.

\begin{abstract}
The coronavirus 19 (COVID-19) pandemic has brought many changes in terms of lifestyle, education, stress levels, and social contacts. The aim of our research was to evaluate changes in eating habits, physical activity, and selected lifestyle elements in a group of school staff, as well as their immune response to vaccination against COVID-19, and FRAP (ferric reducing antioxidant power) level. In total, 108 primary school teachers and other school staff with integration departments were included in the study. An original survey was conducted with the school staff. Of the study group, $45.4 \%$ chose to be vaccinated against COVID-19. In this group, the level of IgG antibodies was assessed, as well as the level of FRAP before vaccination, and after the first and second dose. An original questionnaire was also carried out. A decrease in physical activity and an increase in the time spent in front of the computer have been demonstrated, but a positive observation was a favorable change in most eating habits. After the second dose of vaccination, all subjects achieved the appropriate level of IgG antibodies (above $22 \mathrm{U} / \mathrm{mL}$ ), with the maximum level recorded in $51 \%$. There was also a significant increase in FRAP levels in the group after the first and second dose of the vaccine compared to the baseline level; an issue that requires further observation.
\end{abstract}

Keywords: antioxidants; Poland; lifestyle; diet

\section{Introduction}

The COVID-19 pandemic, i.e., acute respiratory distress syndrome, began in December 2019 in the city of Wuhan in central China, and continues to date [1]. On 30 January 2020, the World Health Organization classified COVID-19 as a public health threat of international concern [2]. Severe Acute Respiratory Syndrome Coronavirus 2 (SARS-CoV-2) is a new type of virus from the coronavirus family. Infection occurs through direct or indirect contact with a sick person and their secretions, especially as a result of talking, coughing, and sneezing [1,3]. SARS-CoV-2 infection can be asymptomatic or accompanied by symptoms, including fever, headache and dizziness, runny nose, joint pain, characteristic loss of smell and taste, and disturbed consciousness [1,3,4]. Complications after passing the virus are varied and are still widely studied. People who have had a hard time of COVID-19 may experience shortness of breath and physical and mental weakness after leaving the hospital. It is not clear how long the complications may persist [5]. The pandemic has caused a number of changes in societies around the world in health, social, and economic life [6]. States have taken appropriate measures to minimize the spread of the virus, such as disinfecting hands, rooms, and equipment, as well as making it compulsory to wear masks [7]. 
The UK was the first Western country to introduce vaccination against SARS-CoV-2 [8]. The World Health Organization (WHO) has officially approved seven types of vaccines. Two contain viral mRNA, three are based on non-replicating viral vectors, and the other two contain inactivated viruses [9]. Some people are concerned about the introduced vaccines, and are withholding a decision to vaccinate [10]. This is due, inter alia, to the lack of confidence in vaccines and the fear of side effects [10,11]. By 21 October 2021, according to $\mathrm{WHO}, 6,655,399,359$ vaccine doses have been administered [12]. It seems that vaccinations can actually have a positive effect on reducing the severity of the disease, which is especially important in the elderly and those with chronic diseases [13]. Vaccinations are designed to stimulate our immune system, to create immune memory, and thus alleviate the course of the disease [14]. According to a 2021 study, the most common symptom reported by $78 \%$ of respondents after the first dose of vaccination was pain at the vaccination site. Other symptoms include pain in the extremities (47\% of respondents), and fatigue (30\%). Malaise, headaches, increased body temperature, and pain in muscles and joints occurred much less frequently [15].

COVID-19 has increased the level of stress in societies around the world. The reasons are, inter alia, uncertainty about work, and the need to quickly adapt to the prevailing conditions [16-18]. Increasing the share of stress also translated into a change in eating habits. Studies have found that the pandemic and related quarantine resulted in higher food consumption, which, in turn, led to weight gain (up to 30\%) [19]. An increase in the consumption of comfort food such as sweets and fast-food was observed $[19,20]$. Moreover, a decrease in physical activity was also noted [21,22]. On the other hand, in smokers, the frequency of smoking increased, and in people addicted to alcohol, there was a higher consumption [19]. These changes also adversely affect the body's resistance by generating oxidative stress. This seems to be particularly important in the prevailing pandemic $[23,24]$. The diet should include ingredients with antioxidant properties, such as polyphenols, antioxidant vitamins (vitamin $C, \beta$-carotene, vitamin $E$, and vitamin D), as well as minerals (zinc, selenium, copper, and manganese) [24,25]. It has been shown that a high content of these components has a positive effect on the antioxidant potential of the organism [26,27]. In the Prevention with Mediterranean Diet (PREDIMED)study, one-year dietary intervention in the form of the Mediterranean diet significantly increased the FRAP index, which assesses the non-enzymatic antioxidant capacity in the blood by reducing iron ions [28]. Antioxidants are present, among others, in vegetables, fruits, nuts, seeds, herbs, and legumes [29-31].

School employees are an important professional group, exposed to contact with many people, unlike, inter alia, administration employees who worked remotely more often. Moreover, these people constitute a model of behavior for their charges; therefore, their behavior may shape the nutritional and health behavior among the young generation.

Due to the fact that the COVID-19 pandemic has caused a number of negative effects, including deterioration in mental and physical health, there is a constant need to investigate this issue. Therefore, the main aim of the study was to assess the eating habits and selected lifestyle elements in a school staff group, and the secondary aim was to assess their immune response to vaccination against COVID-19, and changes in FRAP levels.

\section{Materials and Methods}

\subsection{Ethical Approval}

The study was conducted in accordance with the Helsinki Declaration and Good Clinical Practice, as well as was approved by the Ethics Committee of the Medical University of Bialystok, Poland (approval numbers: APK.002.20.2021, date of approval: 28 January 2021). Informed consent was given by all participants of the study.

\subsection{Study Design and Participants}

In total, 114 school employees residing in the Podlaskie Voivodeship (Bialystok, Poland) were invited to participate in this study. The study participants were employed in 
a primary school with integration departments, in which disabled children were taught. Therefore, despite the pandemic and school closures, this school worked in a hybrid system. This means that the school worked alternately online and stationary.

The survey was conducted from February to May 2021, and included three periods (before vaccination, 10 and 11 February; two weeks after the first dose of vaccination, 24 March; and two weeks after the second dose of vaccination, 19 May). At the first visit, the participants completed the basic questionnaire (participants personally collected the questionnaires, and had the opportunity to get answers to all questions from the persons conducting the research), and blood was collected for testing (the blood was taken by a professional nurse through a venous puncture). Body weight and height were entered independently by the respondents. Out of 114 respondents, we obtained completed questionnaires from 108 people. The subjects who decided to vaccinate against COVID-19 $(45.4 \%)$ were invited to the second and third period of the study. Blood samples were taken again during the second and third period of the study, and an additional questionnaire was used. FRAP and antibodies were tested before, and after the first and second dose of vaccination (Figure 1).

$n=114$

Invitation to participate in the study
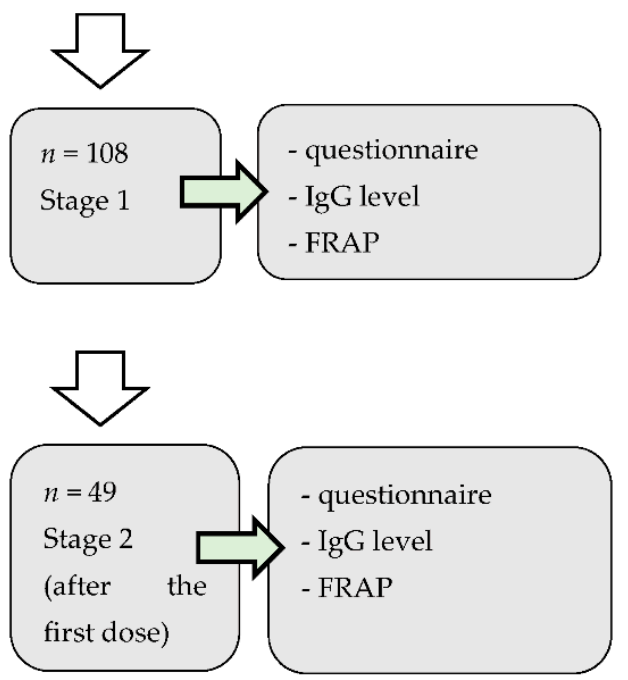

$n=59:$ resignation from

taking the vaccination

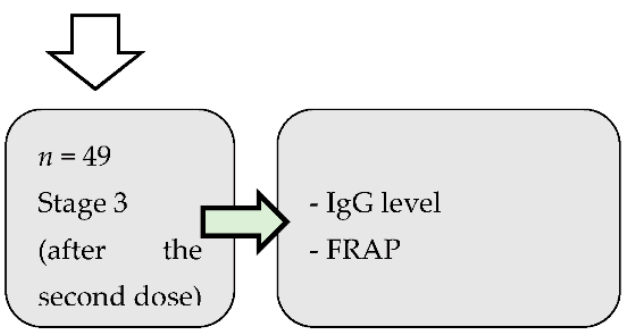

Figure 1. Study scheme. FRAP: ferric reducing antioxidant potential.

The key indicators in our study are: IgG level; FRAP level; and selected anthropometric, lifestyle, and vaccine response aspects. They are characterized below.

\subsection{Applied Questionaires}

The basic questionnaire consisted of three parts: Part 1-questions about gender, age, height, weight, and weight changes during the COVID-19 pandemic, as well as type of work and seniority at school, current form of work (stationary, remotely), and own opinion on the topic of online learning during a pandemic; Part 2-questions about getting COVID19, symptoms and complications, antibody levels, illness among household members, 
being in quarantine, chronic diseases, and vaccination against COVID-19; Part 3-questions about changes in eating habits and lifestyle during the pandemic, including questions about experiencing stress, changes in hygiene habits, smoking, physical activity, changes in the consumption of different groups of products, the amount of food consumed per day, time spent in front of the computer, and hours of sleep (Table S1). An additional questionnaire included questions on the post-vaccination aspects: symptoms experienced and their duration (Table S2).

\subsection{FRAP Assay}

The total antioxidant potential of serum was measured spectrophotometrically using the FRAP (ferric reducing antioxidant power) method according to Benzie and Strain [32] on the spectrophotometer UV-Shimadzu (Shimadzu, Kyoto, Japan). This method is based on the reduction of the $\mathrm{Fe}^{3+}$ ions in the form of a complex with 2,4,6-Tri(2-pyridyl)-striazine (TPTZ) to the $\mathrm{Fe}^{2+}$ ions. The TPTZ- $\mathrm{Fe}^{2+}$ complex has intense color with a maximum absorption at $593 \mathrm{~nm}$ wavelength. The intensity of color is directly proportional to the concentration of $\mathrm{Fe}^{2+}$ ions.

\subsection{Antibodies Assay}

The antibodies were measured in microplate reader (Rayto RT-6100C, Guangzhou, China) at $450 \mathrm{~nm}$, using an immunoenzymatic kit for the determination of IgG antibodies against RBD (receptor-binding domain), Spike S1 protein subunit, and SARS-CoV-2 virus (COVID-19) in human serum or plasma (TestLine Clinical Diagnostics s.r.o., Brno, Czech Republic). The RBD specifically binds to the angiotensin-converting enzyme 2 (ACE2) of the host cell. The binding of RBD to ACE2 is highly associated with the formation of neutralizing antibodies.

The interpretation of the antibody level was as follows: lower than $18 \mathrm{U} / \mathrm{mL}$ is negative, 18 to $22 \mathrm{U} / \mathrm{mL}$ is borderline, and higher than 22 is positive. The maximum level that can be determined with this test is $400 \mathrm{U} / \mathrm{mL}$.

Additionally, the Index of Positivity (IP) was calculated based on the following formula:

$$
\mathrm{IP}=\frac{\text { Absorbance of serum, plasma }}{\text { Mean absorbance of CUT-OFF, }}
$$

where: CUT-OFF—calibrator, $20 \mathrm{U} / \mathrm{mL}$.

\subsection{Statystical Analysis}

Statistical analyses were performed using Statistica v. 13.3 (StatSoft, TIBCO Software Inc., Palo Alto, CA, USA). The results were considered statistically significant for $p<0.05$. The Shapiro-Wilk, Kolmogorov-Smirnov, and Lilliefors tests were used to test the normality of the distribution of variables. The Mann-Whitney U test was used to compare groups without a normal distribution. A chi-squared test was used for variables expressed as categories. Correlations were calculated using the Spearman's test.

\section{Results}

\subsection{Characteristics of the Group}

The first stage of our research involved 108 school employees, including 89 women and 19 men. The mean age of the study group was $46.3 \pm 10.5$ years, and the mean BMI was over $25\left(26.3 \pm 4.3 \mathrm{~kg} / \mathrm{m}^{2}\right)$. The average professional experience of the respondents was $16.6 \pm 12.1$ years. The results are presented as the number of people (Table 1). 
Table 1. Characteristics of the study group $(n=108)$.

\begin{tabular}{cccccc}
\hline Parameter & $\boldsymbol{n}$ & Av. \pm SD & Med. & Min.-Max & Q1-Q3 \\
\hline Gender $(n, \mathrm{~W} / \mathrm{M})$ & $89 / 19$ & - & - & - & - \\
Age $($ years $)$ & 108 & $46.3 \pm 10.5$ & 48.5 & $24.0-70.0$ & $39.5-54.0$ \\
Height $(\mathrm{m})$ & 108 & $168.0 \pm 6.6$ & 168.0 & $153.0-190.0$ & $163.0-170.5$ \\
Body weight $(\mathrm{kg})$ & 108 & $74.0 \pm 13.5$ & 70.0 & $55.0-115.0$ & $63.0-83.0$ \\
BMI $\left(\mathrm{kg} / \mathrm{m}^{2}\right)$ & 108 & $26.3 \pm 4.3$ & 25.6 & $19.3-41.7$ & $23.0-29.1$ \\
Work experience (years) & 108 & $16.6 \pm 12.1$ & 17.5 & $0.5-51.0$ & $4.5-20.5$ \\
\hline
\end{tabular}

Av.-average, M-men, Max-maximum, Med.—median, Min.-minimum, Q1-Q3—quartile 1-quartile 3, SDstandard deviation, $\mathrm{W}-$ women.

Among those who reported an increase in their weight, the highest percentage of the studied group $(39.0 \%)$ reported an increase in body weight by $3-5 \mathrm{~kg}$. The largest percentage of the surveyed school employees conducted classes in grades $0-3(37.0 \%)$ and $4-8(30.6 \%)$. During the completion of the questionnaire, most of the respondents worked stationary $(51.4 \%)$. The vast majority of respondents assessed that distance learning is worse than traditional education $(85.4 \%)$ (Table 2$)$.

Table 2. Baseline characteristic of study groups $(n=108)$.

\begin{tabular}{|c|c|c|c|}
\hline Parameter & Total $(n=108)$ & Women $(n=89)$ & Men $(n=19)$ \\
\hline & $n(\%)$ & $n(\%)$ & $n(\%)$ \\
\hline \multicolumn{4}{|c|}{ Change in weight during a pandemic } \\
\hline No change & $51(47.2)$ & $41(46.1)$ & $10(52.5)$ \\
\hline It was increased in the range of $3-5 \mathrm{~kg}$ & $42(39.0)$ & $36(40.4)$ & $6(31.6)$ \\
\hline It was increased in the range above $10 \mathrm{~kg}$ & $5(4.6)$ & $4(4.5)$ & $1(5.3)$ \\
\hline It was reduced in the range of $3-5 \mathrm{~kg}$ & $1(0.9)$ & $0(0.0)$ & $1(5.3)$ \\
\hline It was reduced in the range of $6-10 \mathrm{~kg}$ & $8(7.4)$ & $7(7.9)$ & $1(5.3)$ \\
\hline It was reduced in the range above $10 \mathrm{~kg}$ & $1(0.9)$ & $1(1.1)$ & $0(0.0)$ \\
\hline \multicolumn{4}{|c|}{ Type of work performed at school (multiple choice question) } \\
\hline Teacher in grades $0-3$ & $40(37.0)$ & $38(42.7)$ & $2(10.5)$ \\
\hline Teacher in grades $4-8$ & $33(30.6)$ & $23(25.8)$ & $10(52.6)$ \\
\hline School administration & $10(9.3)$ & $8(9.0)$ & $2(10.5)$ \\
\hline School service & $29(26.9)$ & $24(27.0)$ & $5(26.4)$ \\
\hline \multicolumn{4}{|c|}{ How do you currently work? } \\
\hline Stationary & $55(51.4)$ & $48(53.9)$ & $7(36.8)$ \\
\hline Remotely & $21(18.7)$ & $13(14.6)$ & $8(42.1)$ \\
\hline Stationary and remotely & $32(29.9)$ & $28(31.5)$ & $4(21.1)$ \\
\hline \multicolumn{4}{|c|}{ How do you rate remote learning during a pandemic? } \\
\hline Comparable to traditional teaching & $16(14.6)$ & $14(15.7)$ & $2(10.5)$ \\
\hline Worse than traditional education & $92(85.4)$ & $75(84.3)$ & $17(89.5)$ \\
\hline
\end{tabular}

\subsection{COVID Infection-Symptoms, Health Background}

Of the study group, $21.3 \%$ of the respondents tested positive for COVID-19: all patients were female, but we did not show statistical significance $(p>0.05)$. Earlier, before our study, $7.4 \%$ of the study group had the level of IgG antibodies determined (Table 3 ). 
Table 3. Experiences with COVID-19 among study group $(n=108)$.

\begin{tabular}{|c|c|c|c|}
\hline Parameter & Total $(n=108)$ & Women $(n=89)$ & $\operatorname{Men}(n=19)$ \\
\hline & $n(\%)$ & $n(\%)$ & $n(\%)$ \\
\hline \multicolumn{4}{|c|}{ Have you been tested positive for COVID-19? } \\
\hline Yes & $23(21.3)$ & $23(25.8)$ & $0(0.0)$ \\
\hline No & $85(78.7)$ & $66(74.2)$ & $19(100.0)$ \\
\hline \multicolumn{4}{|c|}{ Have you had a COVID-19 antibody test performed? } \\
\hline Yes & $8(7.4)$ & $8(9.0)$ & $0(0.0)$ \\
\hline No & $100(92.6)$ & $81(91.0)$ & $19(100.0)$ \\
\hline \multicolumn{4}{|c|}{ If you have had COVID-19, please mark the symptoms accompanying the disease (multiple choice question) } \\
\hline Fever of $38^{\circ} \mathrm{C}$ and above & $11(10.2)$ & $10(11.2)$ & $1(5.3)$ \\
\hline Cough & $10(9.3)$ & $9(10.1)$ & $1(5.3)$ \\
\hline Diarrhea & $3(2.8)$ & $3(3.4)$ & $0(0.0)$ \\
\hline Nausea & $4(3.7)$ & $4(4.5)$ & $0(0.0)$ \\
\hline Vomiting & $1(0.9)$ & $1(1.1)$ & $0(0.0)$ \\
\hline Smell and taste disorders & $16(14.8)$ & $15(16.9)$ & $0(0.0)$ \\
\hline Conjunctivitis & $1(0.9)$ & $1(1.1)$ & $0(0.0)$ \\
\hline Difficulty breathing, difficulty drawing air & $7(6.5)$ & $7(7.9)$ & $0(0.0)$ \\
\hline Muscle aches, fatigue & $15(13.9)$ & $14(15.7)$ & $1(5.3)$ \\
\hline Other symptoms & $7(6.5)$ & $7(7.9)$ & $0(0.0)$ \\
\hline \multicolumn{4}{|c|}{ Have any of your household members had a positive COVID-19 test? } \\
\hline Yes & $14(13.0)$ & $8(9.0)$ & $6(31.6)$ \\
\hline No & $94(87.0)$ & $81(91.0)$ & $13(68.4)$ \\
\hline \multicolumn{4}{|c|}{ Were you in quarantine because of COVID-19? } \\
\hline Yes & $36(33.3)$ & $29(32.6)$ & $7(36.8)$ \\
\hline No & $72(66.7)$ & $60(67.4)$ & $12(63.2)$ \\
\hline \multicolumn{4}{|c|}{ For what reason were you in quarantine? (38 answers) } \\
\hline Own disease & $6(5.6)$ & $6(6.7)$ & $0(0.0)$ \\
\hline Household disease & $15(13.9)$ & $11(12.4)$ & $4(21.1)$ \\
\hline Co-worker disease & $10(9.3)$ & $7(7.9)$ & $3(15.8)$ \\
\hline Return from abroad & $2(1.9)$ & $2(2.2)$ & $0(0.0)$ \\
\hline Another & $5(4.6)$ & $5(5.6)$ & $0(0.0)$ \\
\hline \multicolumn{4}{|c|}{ Do you suffer from chronic diseases? } \\
\hline Yes & $37(34.3)$ & $34(38.2)$ & $3(15.8)$ \\
\hline No & $71(65.7)$ & $55(61.8)$ & $16(84.2)$ \\
\hline \multicolumn{4}{|c|}{ Have you been vaccinated against COVID-19? } \\
\hline No & $109(100.0)$ & $89(100.0)$ & $19(100.0)$ \\
\hline Yes & $0(0.0)$ & $0(0.0)$ & $0(0.0)$ \\
\hline \multicolumn{4}{|c|}{ Would you report your willingness to be vaccinated against COVID-19 if it was possible? } \\
\hline Yes & $61(56.5)$ & $47(52.8)$ & $14(73.7)$ \\
\hline No & $47(43.5)$ & $42(47.2)$ & $5(26.3)$ \\
\hline \multicolumn{4}{|c|}{ If not, why not? (30 answers) } \\
\hline I don't believe vaccination is effective & $3(2.8)$ & $2(2.2)$ & $1(5.3)$ \\
\hline $\begin{array}{c}\text { I do not like the type of vaccine offered to the } \\
\text { education staff }\end{array}$ & $20(18.5)$ & $17(19.1)$ & $3(15.8)$ \\
\hline Other & $7(6.5)$ & $7(7.9)$ & $0(0.0)$ \\
\hline
\end{tabular}


Table 3. Cont.

\begin{tabular}{|c|c|c|c|}
\hline Parameter & Total $(n=108)$ & Women $(n=89)$ & Men $(n=19)$ \\
\hline & $n(\%)$ & $n(\%)$ & $n(\%)$ \\
\hline \multicolumn{4}{|c|}{ If you have had COVID-19, do you think that your current health has returned to its pre-disease state? (23 answers) } \\
\hline Yes & $6(5.6)$ & $6(6.7)$ & $0(0.0)$ \\
\hline No & $17(15.7)$ & $14(15.7)$ & $3(15.8)$ \\
\hline \multicolumn{4}{|c|}{ If you have suffered from COVID-19, what complications do you experience after the illness? (35 answers) } \\
\hline General & $7(6.5)$ & $7(7.9)$ & $0(0.0)$ \\
\hline From the respiratory system & $5(4.6)$ & $5(5.6)$ & $0(0.0)$ \\
\hline From the cardiovascular system & $6(5.6)$ & $6(6.7)$ & $0(0.0)$ \\
\hline Neurological and psychiatric & $8(7.4)$ & $8(9.0)$ & $0(0.0)$ \\
\hline From the gastrointestinal tract & $1(0.9)$ & $1(1.1)$ & $0(0.0)$ \\
\hline From the motor organ & $3(2.8)$ & $3(3.4)$ & $0(0.0)$ \\
\hline From the sensory organs and the throat & $5(4.6)$ & $4(4.5)$ & $1(5.3)$ \\
\hline
\end{tabular}

COVID-19-coronavirus disease.

Respondents indicated that during COVID-19 infection, they mainly had the following symptoms: smell and taste disorders (14.8\%), muscle aches and fatigue (13.9\%), fever of $38{ }^{\circ} \mathrm{C}$ and above (10.2\%), and cough (9.3\%) In our study, $13 \%$ of respondents indicated that their household tested positive for COVID-19 (Table 3)

The most common reason for quarantine was illness of household members; this reason was indicated by $13.9 \%$ of the respondents. About $1 / 3$ of the respondents indicated that they suffer from chronic diseases (34.3\%). None of the respondents had been vaccinated against COVID-19, and 56.5\% declared their willingness to be vaccinated. Of those declaring that they did not want to be vaccinated, the main reason was that they did not like the type of vaccine offered to healthcare professionals (18.5\%) (Table 3$)$.

Among people suffering from COVID-19, 15.7\% declared that their health status did not return to the pre-disease state, and the most frequently declared complications were: neurological and psychiatric (7.4\%), general (6.5\%), and cardiovascular $(5.6 \%)$.

\subsection{Lifestyle}

Further questions were related to lifestyle changes during the pandemic. As many as $77.8 \%$ of respondents declared that they felt stress related to the pandemic: $79.8 \%$ of women and $68.4 \%$ of men. The main cause of anxiety was concern for their own health and that of their family: this was declared by $81.5 \%$ of respondents. Interestingly, as many as $42.6 \%$ of school employees indicated that the cause of stress was concern about the level of the teaching of their students. Hygiene habits changed during the pandemic. As many as $86.1 \%$ of school employees declared wearing the mask in public places, and $73.1 \%$ indicated that they disinfect their hands more often (Table 4).

Only one person indicated that they quit smoking during the pandemic, regular smoking was declared by $7.4 \%$ of respondents, and $3.7 \%$ assessed that they smoked occasionally (Table 4).

Overall, $61.1 \%$ of respondents indicated that their eating habits did not change during the pandemic, and $18.5 \%$ of respondents indicated a negative change (Table 4 ).

It is disturbing to note that the pandemic significantly affected the physical activity of the respondents: as many as $35.2 \%$ of the school employees indicated no activity at all during the pandemic (Table 5). 
Table 4. Lifestyle changes during a pandemic $(n=108)$.

\begin{tabular}{|c|c|c|c|}
\hline Parameter & Total $(n=108)$ & Women $(n=89)$ & Men $(n=19)$ \\
\hline & $n(\%)$ & $n(\%)$ & $n(\%)$ \\
\hline \multicolumn{4}{|c|}{ Do you feel stress related to the pandemic? } \\
\hline Yes & $84(77.8)$ & $71(79.8)$ & $13(68.4)$ \\
\hline No & $24(22.2)$ & $18(20.2)$ & $6(31.6)$ \\
\hline \multicolumn{4}{|c|}{ What is the stress experienced during a pandemic related to? (multiple choice question) } \\
\hline Concern for own and family's health & $88(81.5)$ & $73(82.0)$ & $15(78.9)$ \\
\hline Limited social life & $42(38.9)$ & $36(40.4)$ & $6(31.6)$ \\
\hline Care for job stability and earnings & $31(28.7)$ & $26(29.2)$ & $5(26.3)$ \\
\hline $\begin{array}{c}\text { Online learning and limited access to } \\
\text { computer hardware }\end{array}$ & $18(16.7)$ & $17(19.1)$ & $1(5.3)$ \\
\hline $\begin{array}{c}\text { Concern for the level of the teaching of } \\
\text { their students }\end{array}$ & $46(42.6)$ & $40(44.9)$ & $6(31.6)$ \\
\hline Other & $2(1.9)$ & $2(2.2)$ & $0(0.0)$ \\
\hline \multicolumn{4}{|c|}{ How have your hygiene habits changed during the pandemic? (multiple choice question) } \\
\hline They have not changed & $15(13.9)$ & $13(14.6)$ & $2(10.5)$ \\
\hline I wash my hands more often & $72(66.7)$ & $59(66.3)$ & $13(68.4)$ \\
\hline I disinfect my hands more often & $79(73.1)$ & $66(74.2)$ & $13(68.4)$ \\
\hline I wear the mask in public places & $93(86.1)$ & $76(85.4)$ & $15(78.9)$ \\
\hline Other & $3(2.8)$ & $2(2.2)$ & $0(0.0)$ \\
\hline \multicolumn{4}{|c|}{ Do you smoke cigarettes? } \\
\hline Yes, regularly & $8(7.4)$ & $3(3.4)$ & $5(26.3)$ \\
\hline Yes, occasionally & $4(3.7)$ & $3(3.4)$ & $1(5.3)$ \\
\hline No & $95(88.0)$ & $83(93.2)$ & $12(63.1)$ \\
\hline $\begin{array}{l}\text { I have smoked, but quit during } \\
\text { the pandemic }\end{array}$ & $1(0.9)$ & $0(0.0)$ & $1(5.3)$ \\
\hline \multicolumn{4}{|c|}{ How do you evaluate the change in eating habits during the pandemic? } \\
\hline Positive change & $22(20.4)$ & $20(22.5)$ & $2(10.5)$ \\
\hline Negative change & $20(18.5)$ & $13(14.6)$ & $6(31.6)$ \\
\hline No change & $66(61.1)$ & $55(62.9)$ & $11(57.9)$ \\
\hline
\end{tabular}

Table 5. Physical activity before and during a pandemic $(n=108)$.

\begin{tabular}{ccc}
\hline Physical Activity & Before the Pandemic * $^{*}$ & During a Pandemic \\
\hline & $\boldsymbol{n} \mathbf{( \% )}$ & $\boldsymbol{n} \mathbf{( \% )}$ \\
\hline Lack of physical activity & $23(21.3)$ & $38(35.2)$ \\
$1-2$ times a week, minimum 30 min & $43(39.9)$ & $42(38.9)$ \\
3-5 times a week, minimum 30 min & $25(23.1)$ & $17(15.7)$ \\
More than 5 times a week, & $17(15.7)$ & $11(10.2)$ \\
$\quad$ minimum 30 min & &
\end{tabular}

\subsection{Consumption of Products}

We also assessed how eating habits changed during the pandemic. We found significant increases in the consumption of water (21.3\%); fruits, vegetables, and salads (20.4\%); groats, rice, and cereals (19.4\%); tea (19.4\%); fish and fish products $(16.7 \%)$; honey and bee products $(15.7 \%)$; nuts $(11.1 \%)$; and eggs (10.2\%) (Table 6). 
Table 6. Changes in product consumption during a pandemic $(n=108)$.

\begin{tabular}{ccc}
\hline Product & $\begin{array}{c}\text { Increase } \\
\text { in Consumption }\end{array}$ & $\begin{array}{c}\text { Decrease } \\
\text { in Consumption }\end{array}$ \\
\hline Fruits, vegetables, salads & $\boldsymbol{n}(\mathbf{\%})$ & $\boldsymbol{n}(\mathbf{\%})$ \\
Honey and bee products & $22(20.4)^{* *}$ & $3(2.8)$ \\
Nuts & $17(15.7)^{* * *}$ & $1(0.9)$ \\
Milk and dairy products & $12(11.1)^{*}$ & $3(2.8)$ \\
Meat and meat products & $12(11.1)$ & $5(4.6)$ \\
Fish and processed fish & $12(11.1)$ & $17(15.7)$ \\
Eggs & $18(16.7)^{* *}$ & $3(2.8)$ \\
Bread & $11(10.2)^{*}$ & $2(1.9)$ \\
Groats, rice, cereals & $7(6.5)$ & $14(13.0)$ \\
Flour preparations (pies, & $21(19.4)^{* *}$ & $7(6.5)$ \\
pancakes, rolls, cookies) & $18(16.7)$ & $13(12.0)$ \\
Sweets & $21(19.4)$ & $15(13.9)$ \\
Ready-made dishes for quick & $7(6.5)$ & $25(23.1)^{* *}$ \\
preparation at home & $16(14.8)$ & $13(12.0)$ \\
Coffee & $21(19.4)^{* *}$ & $6(5.6)$ \\
Tea & $10(9.3)$ & $12(11.1)$ \\
Juices & $23(21.3)^{* * *}$ & $4(3.7)$ \\
Water & $3(2.8)$ & $12(11.1) *$ \\
Alcohol & *agnificant differences between groups.
\end{tabular}

${ }^{*} p<0.05,{ }^{* *} p<0.01,{ }^{* * *} p<0.001$-statistically significant differences between groups.

A favorable observation was that the consumption of ready-made dishes for quick preparation at home (23.1\%) and alcohol (11.1\%) decreased (Table 6).

In addition, we recorded an increase in the number of meals consumed during the day: before the pandemic, only $0.9 \%$ said they consumed more than five meals; and during the pandemic, this percentage was as much as $13.0 \%$. The pandemic had a significant impact on the time spent in front of the computer. Before the pandemic, as many as $54.7 \%$ indicated that they spent less than $2 \mathrm{~h}$ in front of the computer a day. During the pandemic, the highest percentage (31.5\%) reported spending 6 to $8 \mathrm{~h}$ in front of the computer. The highest percentage of school employees reported sleeping from 7 to $9 \mathrm{~h}(70.4 \%$ vs. $65.7 \%)$ (Table 7).

Table 7. Changes in eating during a pandemic $(n=108)$.

\begin{tabular}{ccc}
\hline Parameter & Before the Pandemic & During a Pandemic \\
\hline & $\boldsymbol{n} \mathbf{( \% )}$ & $\boldsymbol{n} \mathbf{( \% )}$ \\
\hline 1-2 meals & Number of meals during the day \\
$3-5$ meals & $11(10.2)$ & $10(9.2)$ \\
over 5 meals & $16(88.9)$ & $84(77.8)$ \\
& $1(0.9)$ & $14(13.0)$ \\
\hline less than 2 h a day & Time spent in front of the computer \\
$2-3$ h a day & $59(54.7) * * *$ \\
$4-5$ a day & $31(28.7)$ & $18(16.7)$ \\
$6-8$ h a day & $10(9.2)$ & $15(13.9)$ \\
more than 8 h a day & $3(2.8)$ & $34(31.5)$ \\
& $5(4.6)$ & $20(18.5)$ \\
\hline 6 h or less & Hours of sleep per day & $33(30.6)$ \\
$7-9$ h & $31(28.7)$ & $71(65.7)$ \\
10 or more hours & $76(70.4)$ & $4(3.7)$ \\
\hline *** $p<0.01-$ statistically significant differences between women and men.
\end{tabular}




\subsection{Vaccination}

Assessment of the IgG antibody level in the group of school employees before vaccination $(n=108)$ showed that $53.7 \%$ of the subjects had low levels of antibodies. In the group of people who were vaccinated in the second stage, an antibody level below $18 \mathrm{U} / \mathrm{mL}$ was recorded in $51 \%$. The first dose resulted in a high level of protection (antibody levels above $22 \mathrm{U} / \mathrm{mL}$ were recorded in $89.8 \%$ of school employees), and after the second dose, this was recorded in $100 \%$ of respondents (Table 8). Similar data (percentage of people) were obtained when calculating the percentage of people who responded positively after vaccination (Table 8 ). This table presents the percentage of people depending on the value of the IP parameter.

Table 8. Percentage of people by the IgG and by the rate of positive reaction after vaccination.

\begin{tabular}{|c|c|c|c|c|}
\hline Parameter & $\begin{array}{l}\text { Before Vaccination } \\
\quad(n=108)\end{array}$ & $\begin{array}{l}\text { Before Vaccination } \\
\qquad(n=49)\end{array}$ & $\begin{array}{c}\text { After First } \\
\text { Vaccination }(n=49)\end{array}$ & $\begin{array}{c}\text { After Second } \\
\text { Vaccination }(n=49)\end{array}$ \\
\hline & $n(\%)$ & $n(\%)$ & $n(\%)$ & $n(\%)$ \\
\hline \multicolumn{5}{|c|}{ IG } \\
\hline Under $18 \mathrm{U} / \mathrm{mL}$ & $58(53.7)$ & $25(51.0)$ & $5(10.2)$ & $0(0.0)$ \\
\hline 18-22 U/mL & $8(7.4)$ & $4(8.2)$ & $0(0.0)$ & $0(0.0)$ \\
\hline Above $22 \mathrm{U} / \mathrm{mL}$ & $42(38.9)$ & $20(40.8)$ & $44(89.8)$ & $49(100.0)$ \\
\hline \multicolumn{5}{|c|}{ Index of Positivity } \\
\hline Under 0.9 & $58(53.7)$ & $25(51.0)$ & $5(10.2)$ & $0(0.0)$ \\
\hline $0.9-1.1$ & $8(7.4)$ & $4(8.2)$ & $0(0.0)$ & $0(0.0)$ \\
\hline Above 1.1 & $42(38.9)$ & $20(40.8)$ & $44(89.8)$ & $49(100.0)$ \\
\hline
\end{tabular}

An interesting observation was the significant increase in the FRAP level after the first vaccination and after the second vaccination, compared to the baseline level (1484.0 and 1581.0 vs. 1428) (Table 9).

Table 9. FRAP level in the study group $(n=49)$.

\begin{tabular}{cccc}
\hline Parameter & Av. \pm SD & Med. (Q1-Q3) & $p$ \\
\hline FRAP—before vaccination (A) & $1453.3 \pm 292.2$ & $1428.0(1271.0-1599.0)$ & $p_{\mathrm{A} / \mathrm{B}}<0.0001$ \\
FRAP—after 1 dose (B) & $1539.7 \pm 285.0$ & $1484.0(1346.0-1721.0)$ & $p_{\mathrm{A} / \mathrm{C}<0.0001}$ \\
FRAP—after 2 doses (C) & $1613.1 \pm 294.4$ & $1581.0(1423.0-1787.0)$ & $p_{\mathrm{B} / \mathrm{C}}<0.0001$
\end{tabular}

Av.—average, FRAP—ferric reducing antioxidant power, Med.-median, Q1-Q3-quartile 1-quartile 3, SDstandard deviation.

We also saw a significant increase in antibody levels in the first dose and second dose groups compared to pre-vaccination antibody levels (400.0 and 270 vs. $17.8 \mathrm{U} / \mathrm{mL}$ ) (Table S3).

The preventive vaccinations carried out protected almost the entire studied population of school employees from COVID-19 infection: only one person declared infection after the first dose of the vaccine. The main symptoms in this person were high fever and cough. The people we tested did not have the level of antibodies determined by another laboratory. After vaccination, the main symptoms were: forearm pain $(81.6 \%)$; muscle aches and fatigue (59.1); and shivering and feeling cold (49.0\%). Symptoms in most of the respondents started between 7 and $12 \mathrm{~h}$ (59.1\% of respondents), and usually disappeared after $24 \mathrm{~h}(59.2 \%$ of respondents) (Table S4).

In the further stage of data analysis, we divided the school staff who had been vaccinated into two groups: one group did not reach the maximum level of antibodies that could be demonstrated by the test, and the other group reached the maximum level of $\operatorname{IgG}$ antibodies. We found statistically significant differences only in the case of the antibody level after the first dose of vaccination (140.0 vs. $400, p<0.001)$, and between the IP index 
before vaccination $(0.635$ vs. $1.920, p<0.001)$ and after the first vaccination $(2.670$ vs. 4.380 , $p<0.001)$. These two groups were very similar in terms of anthropometric parameters (Table S5).

We noticed no differences in the change in body weight between the two groups, as well as in the type of work performed, and thus, a different possibility of contact with potential pathogens (Table S6).

Our research confirmed the link between lower antibody levels and no previous COVID-19 disease. Other factors, such as a positive COVID-19 test among household members, and chronic diseases, had no effect. A disturbing observation is the fact that $24 \%$ of respondents with the maximum level of antibodies reported that after infection, they had not yet recovered to their pre-disease state of health (Table S7).

Both groups declared the occurrence of pandemic-related stress to a similar degree, and the main reason was concern for their own health and that of their family $(83.3 \%$ and $80.0 \%$, respectively). A positive change in eating habits was declared by $25.0 \%$ and $20.0 \%$ of the respondents, respectively (Table S8).

The frequency of undertaking physical activity was also not related to the achieved antibody level: no statistical significance was shown (Table S9).

People who achieved the antibody level of $400 \mathrm{U} / \mathrm{mL}$ indicated, inter alia, an increased consumption of fruit, vegetables, and salads, and honey and bee products; however, we noticed that the change in consumption of the analyzed product categories was not related to the body's response to vaccination (Table S10).

We noted a difference between the time spent in front of the computer before the pandemic between the two study groups: $62.4 \%$ spent less than $2 \mathrm{~h}$ a day in front of a computer in the pre-pandemic period, and in the second study group, this was $44.0 \%$ (Table S11).

In the group that did not have peak antibody levels after the second dose, one person developed COVID-19 between the first and second doses. Among post-vaccination symptoms, hand pain was more frequent in the group that reached the maximum antibody level $(88.0 \%$ vs. $75.0 \%)$, but these differences were not statistically significant (Table S12).

By analyzing the correlations between the studied parameters, we saw a significant, very high positive correlation between the level of FRAP before vaccination and after the first dose $(\mathrm{R}=0.92, p<0.0001)$, before vaccination and after the second dose $(\mathrm{R}=0.93$, $p<0.0001)$, and after the first dose and the second dose $(\mathrm{R}=0.97, p<0.0001)$. An interesting, but difficult to explain, observation is the positive correlation between the FRAP level and anthropometric parameters, such as body weight, height, and BMI (Table 10). 
Table 10. Correlations between the selected parameters in the case of people who achieved the maximum level of IgG antibodies, and those with a lower level.

\begin{tabular}{cccc}
\hline Group & \multicolumn{1}{c}{ Parameter 1 } & Parameter 2 & $\mathbf{R}, \boldsymbol{p}$ \\
\hline \multirow{3}{*}{$\begin{array}{c}\text { IgG level below } \\
(n=24)\end{array}$} & FRAP before vaccination & FRAP after first dose & $0.92,0.0001$ \\
\cline { 2 - 4 } & FRAP before vaccination & FRAP after second dose & $0.93,0.0001$ \\
\cline { 2 - 4 } & FRAP after first dose & FRAP after second dose & $0.97,0.0001$ \\
\cline { 2 - 4 } & IgG before vaccination & IgG after first dose & $0.56,0.0042$ \\
\cline { 2 - 4 } & IgG before vaccination & IgG after second dose & $0.55,0.0053$ \\
\hline \multirow{3}{*}{$\begin{array}{c}\text { FRAP after second dose } \\
(n=25)\end{array}$} & FRAP before vaccination & FRAP after first dose & $0.76,0.0001$ \\
\cline { 2 - 4 } & FRAP before vaccination & FRAP after second dose & $0.78,0.0001$ \\
\cline { 2 - 4 } & FRAP before vaccination & BMI & $0.61,0.0013$ \\
\cline { 2 - 4 } & FRAP after first dose & FRAP after second dose & $0.98,0.0001$ \\
\cline { 2 - 4 } & FRAP after first dose & BMI & $0.68,0.0002$ \\
\cline { 2 - 4 } & FRAP after second dose & BMI & $0.70,0.0001$ \\
\hline
\end{tabular}

\section{Discussion}

Teachers and other school employees are a very important social group exposed to daily contact with a large group of young people. For this reason, they should take special care of their health, as well as apply preventive measures.

Our study had two main goals: to assess teachers' and other school employees changes in eating and health habits during the COVID-19 pandemic, and to assess their response to immunization against this viral infection.

During the pandemic, changes in the daily functioning of societies around the world were observed [33]. Phenomena such as limiting social meetings, uncertain financial situations, work, and distance learning contributed to an increase in the levels of stress, which, in turn, translated into changes in the generally understood lifestyle [34]. In this study, $39 \%$ of respondents saw an increase in body weight from 3 to $5 \mathrm{~kg}$ during the pandemic, whereas $47.2 \%$ of respondents did not notice a change. Weight gain was also observed in other studies [19,35-38]. Only $8 \%$ of the subjects lost weight in the range of 6-10 kg. Both weight loss and weight gain could be related to stress. Studies have noticed a negative impact of isolation on well-being and eating behaviors $[39,40]$. It is well known that stress can affect caloric intake in two ways: some people skip meals, whereas some eat more beacause of stress [41]. In a study by Zachary et al. (2020), as many as $52 \%$ of respondents increased food consumption in response to stress [42]. A study by Pellegrini et al. (2020) also noted a correlation between weight gain and increased levels of anxiety/depression [43]. The increased level of anxiety during the pandemic also increased the risk of eating disorders [38,44]. Increased food consumption in some studies concerned overweight, obese, and elderly people, which may have already resulted from previous bad eating habits $[19,45,46]$. In this study, the average BMI value indicated overweight, which, according to the cited studies, may increase the risk of maintaining bad eating habits during the pandemic. Weight gain during COVID-19 may also be associated with decreased activity. In this study, the majority of respondents declared a decrease in physical activity as a result of closed gyms, swimming pools, or other sports-related places. The increase in body weight could therefore be related to the disproportionate consumption of calories to the amount of energy expended. Other studies have found no change, a decrease, as well as an increase in physical activity during the COVID-19 pandemic [37,47-49].

Regarding the change in food consumption, there was a statistically significant increase in the consumption of water (23\%); fruit and vegetables $(22 \%)$; tea (21\%); groats, rice, and cereals $(21 \%)$; fish and pocessed fish (18\%); honey and bee products $(17 \%)$; nuts $(12 \%)$; and 
eggs (11\%). Conversely, there was a decrease in ready-to-eat products $(25 \%)$ and alcohol $(12 \%)$ compared to what was consumed before the pandemic. Increased consumption of vegetables and fruits may result from greater care for the supply of essential vitamins for fear of viral infection. Studies by Silva et al. (2021) and Salman et al. (2021) also noted an increase in the consumption of vegetables and fruits during the pandemic $[49,50]$. It is worth noting that the elderly during the pandemic were characterized by a greater decrease in healthy food consumption than the younger generations [51]. Increased consumption of carbohydrate sources has also been noted in other studies $[19,20,45]$. The increase in the consumption of fish, honey, bee products, and nuts, as in the case of vegetables, could be due to the desire to ensure immunity. Fish, especially sea fish, are a source of valuable anti-inflammatory omega-3 fatty acids. Their positive effect on the immune functions of the body has been shown [52]. Silva et al. (2021) also observed an increase in fish consumption [49]. Honey, bee products, and nuts are also a source of valuable antioxidants, which could have been important when selecting these products [30,53]. An interesting finding is the increased consumption of eggs, which was also noticed by other researchers [54]. The decline in the consumption of ready-made products seems to be a natural phenomenon, because due to remote work and being locked at home, preparing meals was not as difficult as before the pandemic. Additionally, it may have been associated with a desire to save money in uncertain times. In a study by Molina-Montes et al. (2021), $57.8 \%$ of participants reduced the consumption of fast-food dishes, and $52 \%$ cooked more often [55]. Other studies also report a decrease in the consumption of ready meals $[45,49,54]$. A positive change that was observed is the increase in water consumption (23\%). Changes in the consumption of tea and alcohol were also significant. Contrary to the study by Błaszczyk-Bębenek et al. (2020) [54], a decrease in alcohol consumption by 12\% was observed. Similar conclusions were also drawn by Silva et al. (2021) and Ammar et al. (2020) $[49,56]$. This may be due to the limitation of social gatherings, as noted by Rehm et al. (2020) [57]. The 2021 review shows the overall increase in alcohol consumption during the COVID-19 pandemic [58]. On the other hand, no changes in coffee consumption were observed, whereas a statistically significant increase in tea consumption was noted, which is in line with the review by Castellana et al. (2021). As the authors emphasize, tea is associated with relaxation, concentration, and being at home [59]. The increase in the consumption of sweets was not statistically significant. Other researchers obtained different results $[45,49,54]$. An increase in the consumption of sweets was also noted in the review by Gonzalez-Monroy et al. (2021) [58]. Their increased consumption could be associated with an increase in stress accompanying the pandemic [60]. The number of meals per day in this study did not change. In other studies, an increase in food consumption was shown [45,54,61], as well as in snacking [54].

It is well known that a proper diet is necessary to maintain proper immunity. An adequate supply of antioxidant vitamins (vitamin $C, \beta$-carotene, vitamin $E$, and vitamin D), as well as minerals (zinc, selenium, copper, and manganese), polyphenols, and omega-3 fatty acids is particularly important. They regulate the immune system, and thus, reduce the risk of infection. A healthy diet rich in fiber also has a positive effect on the intestinal microbiota, which is extremely important in terms of immunity [62].

Sleep also plays an important role in the context of the body's immunity. Sleep is important to rapidly combat antigens by cytotoxic NK cells, which peak in the waking period, and to repair damaged body tissues [63]. Sleep time did not change during the pandemic among study participants. However, sleep quality is important and, as noted by Wrigth et al. (2021), may worsen during a pandemic due to the increased level of anxiety [64]. An inadequate amount and quality of sleep also affects eating behavior [65]. The time spent in front of the computer has also increased. Before the pandemic, it was less than $2 \mathrm{~h}$ in 59\% of the study participants, whereas during the pandemic, only $18 \%$ of the participants declared this response. This is mainly due to school activities and remote work. This translates into a decrease in physical activity, which was noticed by other researchers [36]. 
An interesting observation was that we found a significant increase in FRAP in people who took the first and second doses of the vaccine. The mechanism of this reaction should be clarified in future research. For example, a decrease in FRAP levels has been observed in patients with active Crohn's disease $(0.01 \mathrm{mmol} / \mathrm{g}$ of protein) compared to FRAP in patients with inactive disease $(0.02 \mathrm{mmol} / \mathrm{g}$ of protein) and controls $(0.02 \mathrm{mmol} / \mathrm{g}$ of protein) [66].

Contreras et al. (2020) conducted a study of the response of animals (cattle) after vaccination against ticks. They measured antioxidant response biomarker parameters, such as: cupric reducing antioxidant capacity (CUPRAC), ferric reducing ability of the plasma (FRAP), trolox equivalent antioxidant capacity (TEAC), total thiol concentrations, and uric acid. The oxidation status was also studied: ferrous oxidation-xylenol orange (FOX), total oxidant status (TOS), advanced oxidation protein products (AOPP), and hydrogen peroxide $\left(\mathrm{H}_{2} \mathrm{O}_{2}\right)$. A significant decrease in oxidizing markers was observed, with the exception of thiol. The authors concluded that those vaccines that are capable of inducing lower oxidative stress allow the production of higher levels of antibodies [67]. In our study, we observed a high level of FRAP in the group after vaccination 2, which was related to the fact that all people had a positive response and a correspondingly high level of antibodies.

Moreover, we found a positive correlation between FRAP and anthropometric parameters, such as height, weight, and BMI. An increase in FRAP in morbidly obese patients was observed by Choromańska et al. (2020) [68]. This can be explained by an increase in uric acid, which is an endogenous antioxidant. This acid accounts for up to $80 \%$ of the total antioxidant potential. In a physiological concentration, it is the most important plasma antioxidant, whereas in higher concentrations, it can generate free radicals (it has pro-inflammatory and pro-oxidative properties). Elevated levels of antioxidant parameters, such as FRAP, may indicate greater ability to remove free radicals, and effective protection against oxidative stress.

In this study, it was found that higher levels of antibodies after vaccination were correlated with higher levels of FRAP, i.e., the body's ability to reduce iron (III) ions. This is an extremely important observation. However, it is difficult to draw definitive conclusions whether it was a diet rich in antioxidants and, at the same time, increasing the antioxidant status of the body that could have influenced a better response to vaccination. There is a lack of research on this topic. A study on piglets showed promising results, in which it was found that the supplementation of antioxidants with hydrated sodium-calcium aluminosilicates (HASC) increased the level of antibodies after vaccination against the porcine reproductive and respiratory syndrome virus. The supplement consisted of viamine $\mathrm{A}$ and $\mathrm{E}$ at a dose of 20,000 IU and $200 \mathrm{IU} / \mathrm{kg}$ feed, respectively, as well as selenized yeast at a dose of $0.3 \mathrm{mg} / \mathrm{kg}$, and grape seed extract at a dose of $100 \mathrm{mg} / \mathrm{kg}$ feed [69].

Changes in eating habits, as well as physical activity, during the COVID-19 pandemic have been noticed by researchers in various parts of the world. It seems that these changes could have been particularly intensified in the initial phase of the pandemic, due to increased stress related to insufficient adaptation to completely new social and economic conditions. It is important to raise public awareness of healthy eating and its impact on the body's immunity. It appears that the antioxidant status of plasma may have a potential impact on increased immune response to vaccination. This is a new issue, and therefore requires careful research.

The positive correlation observed by us between the FRAP level and anthropometric parameters may indicate the need for further research on the nutritional status of the organism, and the relationship with the parameters of oxidative stress.

There are some limitations to this study. Although it was carried out on the largest group available, further studies should be carried out with a larger number of volunteers. Anthropometric measurements were entered independently by the respondents (due to the pandemic). In further studies, measurements should be performed by a specialist, e.g., a dietitian. Another limitation is the disproportion between the number of women and men. Future research should be gender-balanced. The disproportion in our study reflects the actual gender distribution of school workers. 


\section{Conclusions}

The period of the COVID-19 pandemic contributed to a decrease in physical activity among primary school teachers and other school employees, as well as to an increase in the amount of time spent in front of the computer. As this is a conscious and educated group, a compensation for this could be a change in eating habits, including increased consumption of vegetables, fruits, salads, honey and bee products, nuts, fish and processed fish, eggs, groats, rice, cereals, tea, and water; and reduced consumption of ready-made dishes for quick preparation at home, and alcohol. The protective vaccination against COVID-19 contributed to a significant increase in the level of IgG antibodies. There has also been a significant increase in FRAP, but this issue requires further investigation on the link and determination of whether a higher level is a cause or effect.

Supplementary Materials: The following are available online at https: / www.mdpi.com/article/ 10.3390/foods11030408/s1. Table S1: A survey that was carried out in the first stage of the study. Table S2: A survey that was carried out in the second stage of the study. Table S3: Level of IgG in the study group $(n=49)$. Table S4. Respondents' reaction to vaccination with the first dose $(n=49)$. Table S5: Comparison of selected parameters between people who achieved the maximum level of IgG antibodies $(400 \mathrm{U} / \mathrm{mL})$ and the lower level $(n=49)$. Table S6: Comparison of selected aspects of lifestyle between people who achieved the maximum level of IgG antibodies and the lower level $(n=49)$. Table S7: Comparison of selected aspects of symptoms, quarantine and opinions on vaccinations during the COVID-19 pandemic between people who achieved the maximum level of IgG antibodies $(400 \mathrm{U} / \mathrm{mL})$ and the lower level $(n=49)$. Table S8: Comparison of selected aspects of well-being and habits during the COVID-19 pandemic between people who achieved the maximum level of IgG antibodies $(400 \mathrm{U} / \mathrm{mL})$ and the lower level $(n=49)$. Table S9: Comparison of physical activity during the COVID-19 pandemic between people who achieved the maximum level of IgG antibodies $(400 \mathrm{U} / \mathrm{mL})$ and the lower level $(n=49)$. Table S10: Comparison of changing eating habits between people who achieved the maximum level of IgG antibodies $(400 \mathrm{U} / \mathrm{mL})$ and the lower level $(n=49)$. Table S11: Comparison of changing eating habits between people who achieved the maximum level of IgG antibodies $(400 \mathrm{U} / \mathrm{mL})$ and the lower level $(n=49)$. Table S12: Post-vaccination information with 1 dose - comparison between people who achieved the maximum level of IgG antibodies and the lower level $(n=49)$.

Author Contributions: Conceptualization, M.E.Z.; methodology, M.E.Z. and A.P.-J.; software, E.O. and A.P.-J.; validation, M.E.Z.; formal analysis, K.S. and M.E.Z.; investigation, A.P.-J. and E.O.; resources, M.E.Z., A.P.-J. and E.O.; data curation, A.P.-J. and E.O.; writing-original draft preparation, A.P.-J. and E.O.; writing — review and editing, M.E.Z. and K.S.; visualization, A.P.-J. and E.O.; supervision, M.E.Z. and K.S.; project administration, M.E.Z. and K.S.; funding acquisition, K.S. All authors have read and agreed to the published version of the manuscript.

Funding: This research received no external funding.

Institutional Review Board Statement: The study was conducted according to the guidelines of the Declaration of Helsinki, and approved by the Ethics Committee of Medical University of Białystok (protocol code: APK.002.20.2021, and date of approval: 28 January 2021).

Informed Consent Statement: Informed consent was obtained from all subjects involved in the study. Written informed consent has been obtained from the patients to publish this paper.

Data Availability Statement: Detailed data is available from the authors.

Conflicts of Interest: The authors declare no conflict of interest.

\section{References}

1. Wang, C.; Horby, P.W.; Hayden, F.G.; Gao, G.F. A novel coronavirus outbreak of global health concern. Lancet 2020, 395, 470-473. [CrossRef]

2. COVID-19-Public Health Emergency of International Concern (PHEIC) Global Research and Innovation Forum. Available online: https:/ / www.who.int/publications/m/item/covid-19-public-health-emergency-of-international-concern-(pheic)-globalresearch-and-innovation-forum (accessed on 25 October 2021). 
3. $\mathrm{Wu}, \mathrm{Z}$; McGoogan, J.M. Characteristics of and Important Lessons from the Coronavirus Disease 2019 (COVID-19). Outbreak in China: Summary of a Report of 72,314 Cases from the Chinese Center for Disease Control and Prevention. JAMA 2020, 323, 1239-1242. [CrossRef] [PubMed]

4. Chen, X.; Laurent, S.; Onur, O.A.; Kleineberg, N.N.; Fink, G.R.; Schweitzer, F.; Warnke, C. A systematic review of neurological symptoms and complications of COVID-19. J. Neurol. 2021, 268, 392-402. [CrossRef] [PubMed]

5. Weerahandi, H.; Hochman, K.A.; Simon, E.; Blaum, C.; Chodosh, J.; Duan, E.; Garry, K.; Kahan, T.; Karmen-Tuohy, S.L.; Karpel, H.C. Post-Discharge Health Status and Symptoms in Patients with Severe COVID-19. J. Gen. Intern. Med. 2021, 36, 738-745. [CrossRef] [PubMed]

6. Rai, S.S.; Rai, S.; Singh, N.K. Organizational resilience and social-economic sustainability: COVID-19 perspective. Environ. Dev. Sustain. 2021, 23, 12006-12023. [CrossRef] [PubMed]

7. Hsiang, S.; Allen, D.; Annan-Phan, S.; Bell, K.; Bolliger, I.; Chong, T.; Druckenmiller, H.; Huang, L.Y.; Hultgren, A.; Krasovich, E The effect of large-scale anti-contagion policies on the COVID-19 pandemic. Nature 2020, 584, 262-267. [CrossRef] [PubMed]

8. Decision: Regulatory Approval of Pfizer/BioNTech Vaccine for COVID-19. Available online: https://www.gov.uk/government/ publications / regulatory-approval-of-pfizer-biontech-vaccine-for-covid-19 (accessed on 25 October 2021).

9. World Health Organization: 7 Vaccines Approved for Use by WHO. Available online: https://covid19.trackvaccines.org/agency/ who/ (accessed on 25 October 2021).

10. Bendau, A.; Plag, J.; Petzold, M.B.; Ströhle, A. COVID-19 vaccine hesitancy and related fears and anxiety. Int. Immunopharmacol. 2021, 97, 107724. [CrossRef] [PubMed]

11. Rzymski, P.; Zeyland, J.; Poniedziałek, B.; Małecka, I.; Wysocki, J. The Perception and Attitudes toward COVID-19 Vaccines: A Cross-Sectional Study in Poland. Vaccines 2021, 9, 382. [CrossRef] [PubMed]

12. World Health Organization: WHO Coronavirus (COVID-19) Dashboard. Available online: https://covid19.who.int/ (accessed on 25 October 2021).

13. Lopez Bernal, J.; Andrews, N.; Gower, C.; Robertson, C.; Stowe, J.; Tessier, E.; Simmons, E.; Cottrell, S.; Roberts, E.; O’'Doherty, M.; et al. Effectiveness of the Pfizer-BioNTech and Oxford-AstraZeneca vaccines on COVID-19 related symptoms, hospital admissions, and mortality in older adults in England: Test negative case-control study. BMJ 2021, 373, n1088. [CrossRef] [PubMed]

14. Fathizadeh, H.; Afshar, S.; Masoudi, M.R.; Gholizadeh, P.; Asgharzadeh, M.; Ganbarov, K.; Köse, S.; Yousefi, M.; Kafil, H.S. SARS-CoV-2 (Covid-19) vaccines structure, mechanisms and effectiveness: A review. Int. J. Biol. Macromol. 2021, 188, 740-750. [CrossRef]

15. Jeśkowiak, I.; Wiatrak, B.; Grosman-Dziewiszek, P.; Szelag, A. The Incidence and Severity of Post-Vaccination Reactions after Vaccination against COVID-19. Vaccines 2021, 9, 502. [CrossRef] [PubMed]

16. Taylor, S.; Landry, C.A.; Paluszek, M.M.; Fergus, T.A.; McKay, D.; Asmundson, G.J.G. COVID stress syndrome: Concept, structure, and correlates. Depress. Anxiety 2020, 37, 706-714. [CrossRef] [PubMed]

17. Kumar, A.; Nayar, K.R. COVID 19 and its mental health consequences. J. Ment. Health 2020, 30, 1-2. [CrossRef] [PubMed]

18. Valeria, S.; Davide, A.; Vincenzo, A. The Psychological and Social Impact of COVID-19: New Perspectives of Well-Being. Front. Psychol. 2020, 11, 25-50. [CrossRef]

19. Sidor, A.; Rzymski, P. Dietary Choices and Habits during COVID-19 Lockdown: Experience from Poland. Nutrients 2020, $12,1657$. [CrossRef] [PubMed]

20. Scarmozzino, F.; Visioli, F. COVID-19 and the Subsequent Lockdown Modified Dietary Habits of Almost Half the Population in an Italian Sample. Foods 2020, 9, 675. [CrossRef]

21. Castañeda-Babarro, A.; Arbillaga-Etxarri, A.; Gutiérrez-Santamaría, B.; Coca, A. Physical Activity Change during COVID-19 Confinement. Int. J. Environ. Res. Public Health 2020, 17, 6878. [CrossRef]

22. Izzo, L.; Santonastaso, A.; Cotticelli, G.; Federico, A.; Pacifico, S.; Castaldo, L.; Colao, A.; Ritieni, A. An Italian Survey on Dietary Habits and Changes during the COVID-19 Lockdown. Nutrients 2021, 13, 1197. [CrossRef]

23. Rahal, A.; Kumar, A.; Singh, V.; Yadav, B.; Tiwari, R.; Chakraborty, S.; Dhama, K. Oxidative Stress, Prooxidants, and Antioxidants: The Interplay. Biomed. Res. Int. 2014, 2014, 761264. [CrossRef]

24. Pisoschi, A.M.; Pop, A. The role of antioxidants in the chemistry of oxidative stress: A review. Eur. J. Med. Chem. 2015, 97, 5574. [CrossRef]

25. Gostner, J.M.; Becker, K.; Ueberall, F.; Fuchs, D. The good and bad of antioxidant foods: An immunological perspective. Food Chem. Toxicol. 2015, 80, 7279. [CrossRef] [PubMed]

26. Harasym, J.; Oledzki, R. Effect of fruit and vegetable antioxidants on total antioxidant capacity of blood plasma. Nutrition 2014, 30, 511-517. [CrossRef] [PubMed]

27. Puchau, B.; Zulet, M.A.; González de Echávarri, A.; Hermsdorff, H.H.M.; Martínez, J.A. Dietary total antioxidant capacity is negatively associated with some metabolic syndrome features in healthy young adults. Nutrition 2010, 26, 534-541. [CrossRef] [PubMed]

28. Zamora-Ros, R.; Serafini, M.; Estruch, R.; Lamuela-Raventós, R.M.; Martínez-González, M.A.; Salas-Salvadó, J.; Fiol, M.; Lapetra, J.; Arós, F.; Covas, M.I.; et al. Mediterranean diet and non enzymatic antioxidant capacity in the PREDIMED study: Evidence for a mechanism of antioxidant tuning. Nutr. Metab. Cardiovasc. Dis. 2013, 23, 1167-1174. [CrossRef] [PubMed]

29. Lourenço, S.C.; Moldão-Martins, M.; Alves, V.D. Antioxidants of Natural Plant Origins: From Sources to Food Industry Applications. Molecules 2019, 24, 4132. [CrossRef] 
30. Zujko, M.; Witkowska, A. Antioxidant Potential and Polyphenol Content of Beverages, Chocolates, Nuts, and Seeds. Int. J. Food Prop. 2014, 17, 86-92. [CrossRef]

31. Zujko, M.; Witkowska, A. Antioxidant Potential and Polyphenol Content of Selected Food. Int. J. Food Prop. 2011, 14, 300-308. [CrossRef]

32. Benzie, I.F.; Strain, J.J. The ferric reducing ability of plasma (FRAP) as a measure of "antioxidant power": The FRAP assay. Anal. Biochem. 1996, 239, 70-76. [CrossRef]

33. Bakaloudi, D.R.; Barazzoni, R.; Bischoff, S.C.; Breda, J.; Wickramasinghe, K.; Chourdakis, M. Impact of the first COVID-19 lockdown on body weight: A combined systematic review and a meta-analysis. Clin. Nutr. 2021. [CrossRef]

34. Brooks, S.K.; Webster, R.K.; Smith, L.E.; Woodland, L.; Wessely, S.; Greenberg, N.; Rubin, G.J. The psychological impact of quarantine and how to reduce it: Rapid review of the evidence. Lancet 2020, 395, 912-920. [CrossRef]

35. Maffoni, S.; Brazzo, S.; De Giuseppe, R.; Biino, G.; Vietti, I.; Pallavicini, C.; Cena, H. Lifestyle Changes and Body Mass Index during COVID-19 Pandemic Lockdown: An Italian Online-Survey. Nutrients 2021, 13, 1117. [CrossRef] [PubMed]

36. Czenczek-Lewandowska, E.; Wyszyńska, J.; Leszczak, J.; Baran, J.; Weres, A.; Mazur, A.; Lewandowski, B. Health behaviours of young adults during the outbreak of the COVID-19 pandemic-A longitudinal study. BMC Public Health 2021, 21, 1038. [CrossRef] [PubMed]

37. Al-Domi, H.; AL-Dalaeen, A.; AL-Rosan, S.; Batarseh, N.; Nawaiseh, H. Healthy nutritional behavior during COVID-19 lockdown: A cross-sectional study. Clin. Nutr. ESPEN 2021, 42, 132-137. [CrossRef]

38. Elmacıŏ̆lu, F.; Emiroğlu, E.; Ülker, M.; Özyılmaz Kırcali, B.; Oruç, S. Evaluation of nutritional behaviour related to COVID-19. Public Health Nutr. 2021, 24, 512-518. [CrossRef] [PubMed]

39. Coulthard, H.; Sharps, M.; Cunliffe, L.; van den Tol, A. Eating in the lockdown during the COVID-19 pandemic; self-reported changes in eating behaviour, and associations with BMI, eating style, coping and health anxiety. Appetite 2021, 161, 105082. [CrossRef] [PubMed]

40. Cecchetto, C.; Aiello, M.; Gentili, C.; Ionta, S.; Osimo, S.A. Increased emotional eating during COVID-19 associated with lockdown, psychological and social distress. Appetite 2021, 160, 105122. [CrossRef]

41. Yau, Y.H.; Potenza, M.N. Stress and eating behaviors. Minerva Endocrinol. 2013, 38, 255-267.

42. Zachary, Z.; Brianna, F.; Brianna, L.; Garrett, P.; Jade, W.; Alyssa, D.; Mikayla, K. Self-quarantine and weight gain related risk factors during the COVID-19 pandemic. Obes. Res. Clin. Pract. 2020, 14, 210-216. [CrossRef] [PubMed]

43. Pellegrini, M.; Ponzo, V.; Rosato, R.; Scumaci, E.; Goitre, I.; Benso, A.; Belcastro, S.; Crespi, C.; De Michieli, F.; Ghigo, E.; et al Changes in Weight and Nutritional Habits in Adults with Obesity during the "Lockdown" Period Caused by the COVID-19 Virus Emergency. Nutrients 2020, 12, 2016. [CrossRef] [PubMed]

44. Flaudias, V.; Iceta, S.; Zerhouni, O.; Rodgers, R.F.; Billieux, J.; Llorca, P.M.; Boudesseul, J.; de Chazeron, I.; Romo, L.; Maurage, P.; et al. COVID-19 pandemic lockdown and problematic eating behaviors in a student population. J. Behav. Addict. 2020, 9, 826-835. [CrossRef]

45. Huber, B.C.; Steffen, J.; Schlichtiger, J.; Brunner, S. Altered nutrition behavior during COVID-19 pandemic lockdown in young adults. Eur. J. Nutr. 2021, 60, 2593-2602. [CrossRef] [PubMed]

46. Poelman, M.P.; Gillebaart, M.; Schlinkert, C.; Dijkstra, S.C.; Derksen, E.; Mensink, F.; Hermans, R.C.J.; Aardening, P.; de Ridder, D.; de Vet, E. Eating behavior and food purchases during the COVID-19 lockdown: A cross-sectional study among adults in the Netherlands. Appetite 2021, 157, 105002. [CrossRef] [PubMed]

47. Kass, L.; Desai, T.; Sullivan, K.; Muniz, D.; Wells, A. Changes to Physical Activity, Sitting Time, Eating Behaviours and Barriers to Exercise during the First COVID-19 'Lockdown' in an English Cohort. Int. J. Environ. Res. Public Health 2021, 18, 10025. [CrossRef] [PubMed]

48. Robertson, M.; Duffy, F.; Newman, E.; Bravo, C.P.; Ates, H.H.; Sharpe, H. Exploring changes in body image, eating and exercise during the COVID-19 lockdown: A UK survey. Appetite 2021, 159, 105062. [CrossRef] [PubMed]

49. Silva, M.N.; Gregório, M.J.; Santos, R.; Marques, A.; Rodrigues, B.; Godinho, C.; Silva, C.S.; Mendes, R.; Graça, P.; Arriaga, M.; et al. Towards an In-Depth Understanding of Physical Activity and Eating Behaviours during COVID-19 Social Confinement: A Combined Approach from a Portuguese National Survey. Nutrients 2021, 13, 2685. [CrossRef] [PubMed]

50. Salman, A.; Sigodo, K.O.; Al-Ghadban, F.; Al-Lahou, B.; Alnashmi, M.; Hermassi, S.; Chun, S. Effects of COVID-19 Lockdown on Physical Activity and Dietary Behaviors in Kuwait: A Cross-Sectional Study. Nutrients 2021, 13, 2252. [CrossRef]

51. Ogundijo, D.A.; Tas, A.A.; Onarinde, B.A. Exploring the Impact of COVID-19 Pandemic on Eating and Purchasing Behaviours of People Living in England. Nutrients 2021, 13, 1499. [CrossRef]

52. Gutiérrez, S.; Svahn, S.L.; Johansson, M.E. Effects of Omega-3 Fatty Acids on Immune Cells. Int. J. Mol. Sci. 2019, $20,5028$. [CrossRef]

53. Erejuwa, O.O.; Sulaiman, S.A.; Ab Wahab, M.S. Honey: A Novel Antioxidant. Molecules 2012, 17, 4400-4423. [CrossRef]

54. Błaszczyk-Bębenek, E.; Jagielski, P.; Bolesławska, I.; Jagielska, A.; Nitsch-Osuch, A.; Kawalec, P. Nutrition Behaviors in Polish Adults before and during COVID-19 Lockdown. Nutrients 2020, 12, 3084. [CrossRef]

55. Molina-Montes, E.; Uzhova, I.; Verardo, V.; Artacho, R.; García-Villanova, B.; Guerra-Hernández, E.J.; Kapsokefalou, M.; Malisova, O.; Vlassopoulos, A.; Katidi, A.; et al. Impact of COVID-19 confinement on eating behaviours across 16 European countries: The COVIDiet cross-national study. Food Qual. Prefer. 2021, 93, 104231. [CrossRef] 
56. Ammar, A.; Brach, M.; Trabelsi, K.; Chtourou, H.; Boukhris, O.; Masmoudi, L.; Bouaziz, B.; Bentlage, E.; How, D.; Ahmed, M.; et al. Effects of COVID-19 Home Confinement on Eating Behaviour and Physical Activity: Results of the ECLB-COVID19 International Online Survey. Nutrients 2020, 12, 1583. [CrossRef] [PubMed]

57. Rehm, J.; Kilian, C.; Ferreira-Borges, C.; Jernigan, D.; Monteiro, M.; Parry, C.D.H.; Sanchez, Z.M.; Manthey, J. Alcohol use in times of the COVID 19: Implications for monitoring and policy. Drug Alcohol Rev. 2020, 39, 301-304. [CrossRef] [PubMed]

58. González-Monroy, C.; Gómez-Gómez, I.; Olarte-Sánchez, C.M.; Motrico, E. Eating Behaviour Changes during the COVID-19 Pandemic: A Systematic Review of Longitudinal Studies. Int. J. Environ. Res. Public Health 2021, 18, 11130. [CrossRef] [PubMed]

59. Castellana, F.; De Nucci, S.; De Pergola, G.; Di Chito, M.; Lisco, G.; Triggiani, V.; Sardone, R.; Zupo, R. Trends in Coffee and Tea Consumption during the COVID-19 Pandemic. Foods 2021, 10, 2458. [CrossRef] [PubMed]

60. Sánchez-Sánchez, E.; Díaz-Jimenez, J.; Rosety, I.; Alférez, M.J.M.; Díaz, A.J.; Rosety, M.A.; Ordonez, F.J.; Rosety-Rodriguez, M. Perceived Stress and Increased Food Consumption during the 'Third Wave' of the COVID-19 Pandemic in Spain. Nutrients 2021, 13, 2380. [CrossRef] [PubMed]

61. Buckland, N.J.; Swinnerton, L.F.; Ng, K.; Price, M.; Wilkinson, L.L.; Myers, A.; Dalton, M. Susceptibility to increased high energy dense sweet and savoury food intake in response to the COVID-19 lockdown: The role of craving control and acceptance coping strategies. Appetite 2021, 158, 105017. [CrossRef] [PubMed]

62. Calder, P.C. Nutrition, immunity and COVID-19. BMJ Nutr. Prev. Health 2020, 3, 74-92. [CrossRef] [PubMed]

63. Besedovsky, L.; Lange, T.; Born, J. Sleep and immune function. Pflug. Arch.-Eur. J. Physiol. 2012, 463, 121-137. [CrossRef]

64. Wright, L.; Steptoe, A.; Fancourt, D. Are adversities and worries during the COVID-19 pandemic related to sleep quality? Longitudinal analyses of 46,000 UK adults. PLoS ONE 2021, 16, e0248919. [CrossRef]

65. Du, C.; Zan, M.C.H.; Cho, M.J.; Fenton, J.I.; Hsiao, P.Y.; Hsiao, R.; Keaver, L.; Lai, C.-C.; Lee, H.; Ludy, M.-J.; et al. The Effects of Sleep Quality and Resilience on Perceived Stress, Dietary Behaviors, and Alcohol Misuse: A Mediation-Moderation Analysis of Higher Education Students from Asia, Europe, and North America during the COVID-19 Pandemic. Nutrients 2021, 13, 442. [CrossRef] [PubMed]

66. Szczeklik, K.; Krzyściak, W.; Cibor, D.; Domagała-Rodacka, R.; Pytko-Polończyk, J.; Mach, T.; Owczarek, D. Markers of lipid peroxidation and antioxidant status in the serum and saliva of patients with active Crohn disease. Pol. Arch. Intern. Med. 2018, 128, 362-370. [CrossRef] [PubMed]

67. Contreras, M.; Peres Rubio, C.; de la Fuente, J.; Villar, M.; Merino, O.; Mosqueda, J.; Cerón, J.J. Changes in serum biomarkers of oxidative stress in cattle vaccinated with tick recombinant antigens: A pilot study. Vaccines 2020, 9, 3965. [CrossRef] [PubMed]

68. Choromańska, B.; Myśliwiec, P.; Łuba, M.; Wojskowicz, P.; Myśliwiec, H.; Choromańska, K.; Żendzian-Piotrowska, M.; Dadan J.; Zalewska, A.; Maciejczyk, M. Impact of Weight Loss on the Total Antioxidant/Oxidant Potential in Patients with Morbid Obesity-A Longitudinal Study. Antioxidants 2020, 9, 376. [CrossRef]

69. Verso, L.L.; Dumont, K.; Lessard, M.; Lauzon, K.; Provost, C.; Gagnon, C.A.; Chorfi, Y.; Guay, F. The administration of diets contaminated with low to intermediate doses of deoxynivalenol and supplemented with antioxidants and binding agents slightly affects the growth, antioxidant status, and vaccine response in weanling pigs. Sci. J. Anim. Sci. 2021, 99, skab238. [CrossRef] 